\title{
The autonomous interpretation method in international law with particular reference to the proposed European Sales Law II
}

\author{
by Maren Heidemann
}

\section{(C) OBJECTS AND PURPOSES IN DTCS}

An indication of the object and purpose may be the title of the convention. The German UK Double Tax Convention is entitled: "Convention of 26 November 1964 between the Federal Republic of Germany and the United Kingdom of Great Britain and Northern Ireland for the Avoidance of Double Taxation and the Prevention of Fiscal Evasion.'

Clearly, the conception in both countries of the very same contractual arrangement amounting to the "atypical silent partnership" has the potential of leading to double taxation. Therefore a reconciliation of the understanding in both jurisdictions is desirable in order to achieve the first of the two purposes. The drafters of the convention seem to have relied on the fact that the convention will usually be applied by only one contracting state which then applies its own law under Article II (3) DTC. If a conflict arises it can be resolved according to the rules in Articles XVIII and XVIIIA, elimination of double taxation (including crediting tax paid) and mutual agreement procedure which can also be invoked by the taxpayer.

Therefore, the so-called conflicts of qualification may actually be a conscious choice of the contracting parties.

The question is why an enumeration of cases triggering business profits or dividends is then necessary at all. Articles II to XVI clearly seek to establish the distribution of income between the two contracting states mainly according to the place of residence of the taxpayer and according to the location of the source it is derived from as exceptions (PEs, immovable property etc). Article XVIII on the other hand, seems to adhere to a "first-come-first-served" principle. Finally, the taxpayer can, according to Article XVIIIA, seek an "appropriate" application of the DTC without being expressly limited to avoiding double taxation or fiscal evasion if "the actions of one or both of the Contracting Parties result or will result for him in taxation not in accordance with this Convention" (Art XVIIIA (1)). This means that the correct application of the treaty itself is a value in that provision.

There are a number of express, likely and unspoken objectives and purposes of the convention, and these might even be in conflict with each other. The content of the convention may not reflect the objectives and purposes accurately, or the objectives and purposes may not have been achieved by the content of the convention.

A misalignment between the declared or underlying object and purpose and the actual content of a convention or other uniform instrument will impact on the quality of the interpretation and hence its application. The more politicised a convention is, the higher the possibility for such misalignments. In the case of double taxation conventions the motivations and driving forces behind the conclusion of those are distinctly fraught: a natural conflict occurs when states decide to compromise by making concessions on their right to tax (ie on fiscal sovereignty which is considered one of the most important elements of state sovereignty), supposedly for the benefit of migrating taxpayers and partner states. Some objectives may not be openly admitted, and some may be only reluctantly followed, leading to half-hearted drafts and subtle hints. Experience in international negotiations and observing the slow process even within the EU makes it very clear how jealously states guard their positions in this area.

\section{(D) ARTICLE 31(3) LIT.B VCLT - SUBSEQUENT PRACTICE}

Can the German treatment of the silent partner be based on a subsequent practice according to Article 31 (3) lit.b VCLT?

A 1992 decision of the German supreme tax court suggests that this is not the case. It concerned dividends paid to US tax payer which the German authorities sought to treat as business profits and tax in Germany. The court held that this practice was against the DTC US-D and the fact that the US 
authorities had not intervened (because they most likely did not know about this just as the UK authorities in Memec) did not establish a subsequent practice under Article 31(3) of the 1969 Vienna Convention of the Law of Treaties (VCLT - this rule was not expressly mentioned). Here, for the first time, the element of mutuality is resonating. The subsequent practice cannot be unilateral.

This clearly shows the conflict between Article II(3) DTC D-UK, Article 3(2) of the OECD Model Tax Convention respectively, and the VCLT Art II(3) seems to suggest that the unilateral element is justified. It seems to work as a conflict rule, referring any matter where the convention is unilaterally applied to domestic law. But as set out above, Article II(3) is really not a method article, as it is called in most commentaries. It is an interpretation rule. The convention does not contain a method article. To conceive Article II(3) as providing a method, providing a step away from the convention and into domestic law, means depriving the convention of its international character. It defeats the purpose of creating an international agreement about international (ie cross border) situations. It steps out of the scenario of distributing tax income between two states and refers everything back into the "applying" state, conferring a prerogative onto the applying state. By inverse conclusion, this could mean that there is no such objective as achieving a fair distribution of income between the contracting states (see M Schönhaus, "Die Behandlung der stillen Gesellschaft im Recht der Doppelbesteuerungsabkommen unter besonderer Berücksichtigung des OECD"-PartnershipReports (Europäische Hochschulschriften, Peter Lang, Frankfurt etc 2005), pp 42-43). Nevertheless, the correct application of the instrument seems to be a value in itself.

\section{(E) MODERN APPROACH}

This value or objective is more clearly visible in the GermanSwedish DTC of 1992.

The German Swedish DTC of 1992 opens a new chapter in DTC drafting. Not only does it cover a wider range of taxes, including inheritance and gift taxes, displays a different title compared to the earlier DTCs:

Abkommen zwischen der Bundesrepublik Deutschland und dem Königreich Schweden zur Vermeidung der Doppelbesteuerung bei den Steuern vom Einkommen und vom Vermögen sowie bei den Erbschafts- und Schenkungssteuern und zur Leistung gegenseitigen Beistands bei den Steuern (Deutsch-schwedisches Steuerabkommen)

[Agreement between the Federal Republic of Germany and the Kingdom of Sweden about the avoidance of double taxation of taxes on income and assets as well on inheritance and gifts and about mutual assistance with taxes] (German-Swedish tax agreement - BStBl 1994 I
S. 422, BGBl. 1994 II S. 686).

- but also includes a novel clause regarding interpretation of the convention which is not contained in the OECD Model, Article 3(2).

Artikel 3 - Article 3

Allgemeine Begriffsbestimmungen (General definitions)

(2) Dieses Abkommen ist bei seiner Anwendung durch beide Vertragsstaaten übereinstimmend aus sich selbst heraus auszulegen. Ein in diesem Abkommen nicht definierter Ausdruck hat jedoch dann die Bedeutung, die ihm nach dem Recht des anwendenden Staates zukommt, wenn der Zusammenhang dies erfordert und die zuständigen Behörden sich nicht auf eine gemeinsame Auslegung geeinigt haben (Artikel 39 Absatz 3, Artikel 40 Absatz 3).

[An interpretation of this convention is to be derived from the convention itself when applied by both contracting states. A term which is not defined in this convention however, has the meaning which it has according to the law of the applying state if the context so requires and if the competent authorities have not reached an agreement on a joint interpretation, Art 39(3) and Art 40(3)].

Finally, the corresponding scenario to the unilateral application is part of the equation, and it includes the treaty specific interpretation. The necessity to consider the treaty context is reinforced by becoming a condition for interpreting a term according to domestic law, not an outer limit.

The German Swedish DTC clearly also includes the interest of the taxpayer into the objectives and purpose of the convention. It describes a right to a "coordinated application of the convention", Article 39(3). It gives "a person" the right to refer the matter to the tax authority in his or her country of residence or even that of the other country, Article 40(1).

Artikel 39 - Article 39

Konsultation - Consultation

(3) Die zuständigen Behörden der Vertragsstaaten können gemeinsam über allgemeine Regelungen beraten, um auf der Grundlage des Abkommens den Anspruch der Steuerpflichtigen auf abgestimmte Anwendung des Abkommens in beiden Staaten durch gemeinsame Auslegungen oder durch besondere Verfahren zu sichern.

[The ...authorities... can conduct joint consultations in order to secure the taxpayer's right to a co-ordinated application of the convention in both states by way of joint interpretation or special procedures.]

Artikel 40 - Article 40 
Verständigung - mutual agreement

(1)Ist eine Person der Auffassung, daß Maßnahmen eines Vertragsstaats oder beider Vertragsstaaten für sie zu einer Besteuerung führen oder führen werden, die diesem Abkommen nicht entspricht, so kann sie unbeschadet der nach dem innerstaatlichen Recht dieser Staaten vorgesehenen Rechtsbehelfe ihren Fall der zuständigen Behörde des Vertragsstaats, in dem sie ansässig ist, oder, sofern ihr Fall von Artikel 38 Absatz 1 erfaßt wird, der zuständigen Behörde des Vertragsstaats unterbreiten, dessen Staatsangehöriger sie ist.

[A person is entitled to refer his or her case to the authorities of his or her state of residence or nationality irrespective of national procedure if they think that measures taken by one or both contracting states will lead to a taxation that does not comply with this convention.]

(2)Hält die zuständige Behörde die Einwendung für begründet und ist sie selbst nicht in der Lage, eine befriedigende Lösung herbeizuführen, so wird sie sich bemühen, den Fall durch Verständigung mit der zuständigen Behörde des anderen Vertragsstaats so zu regeln, daß eine dem Abkommen nicht entsprechende Besteuerung vermieden wird. ...

[If the competent authority considers the complaint justified... they can seek an understanding with... the other contracting state, in order to resolve the case in such a way that a taxation that does not comply with this convention is avoided].

An evolution has taken place between Article II(3) DTC D-UK and Article 3(2) DTC D-S towards the autonomous interpretation method. There is a clear preference for mutual understanding and interpretation in this article, and the unilateral interpretation is made into a last resort. To eliminate this unilateral element entirely, however, still seems to be politically unattainable.

Uniformity in its application

The question arises whether value can be derived from this DTC for the interpretation of others, so that it would affect the treatment of the "silent partner" under the German-British DTC. This idea was considered by the judges in Memec.

In the absence of a directly corresponding German decision on the same DTC, considerations arose as to what extent findings under different DTCs would have an effect on the interpretation problem in hand. While Robert Walker J pointed to the requirement of a symmetrical interpretation of the conventions in different states, Sir Christopher Staughton considered that this requirement would be stronger in regard to multilateral conventions than bilateral ones. He saw in such a multilateral element the possibility of relating different DTCs of the German-Swiss DTC of 1982 which

has similar wording; and it is very probable that a great many others do, since some such wording is to be found in the Model Tax Convention on Income and on Capital of the OECD... (Memec plc v Inland Revenue Commissioners (IRC) [1998] STC, $754,771(C A))$.

This argument possibly suggests the development of international precedent in the area of cross-border taxation. It is questionable, though, to what extent the DTCs themselves can influence each other, being separately negotiated instruments always reflecting the specific requirements between two states. Rather, the VCLT, together with established principles of international law, written and customary, provides the overarching platform and reference for interpretation guidance.

\section{. and observance of its international character}

The wording of Model Article 3(2), which is very similar to Article II(3) of the DTC UK-D, seems to be a derogation of Article 30 of the VCLT. The VCLT was not in force at the time of the conclusion of the DTC, but very much so during the numerous updates of the model. The "derogation" seems to be based on the fact that only "one of the contracting parties" applies the convention. It is an agreement not to agree on interpretation and to accept unilateral determination. The avoidance, or at least mitigation, of the resulting discrepancy of understanding and interpretation and application is the subject of Article 31 VCLT.

It appears that DTCs are very much conventions sui generis and considerably lack an element of reciprocity which can normally be assumed to be a key element of any treaty.

To mitigate this impression, one reading of Article 3(2) of the model could be that both the element of the interpretation article and the meaning of the respective term in domestic law have to be established in the context of the convention according to Article 31-33 VCLT.

Elements of such a reading can be found in the abovementioned German decisions and certainly in English case law, including Memec and Fothergill. It should be acceptable to domestic tax authorities to give a term a meaning for the purposes of the DTC. It is conceivable that "silent partner" means just that, and that the subtlety of him or her being "atypical" is not transportable into English law and convention law. The fact that English law does not recognise this notion, based on such thorough argument as carried out in Memec, and that the UK is going to be deprived of the taxation on the proceeds of the silent partnership is a strong argument in favour of an interpretation that denies that there is room for differentiation given that the "atypical" silent partner is still a silent partner. On the other hand, there are certain elements 
in the wording of ArticleVI(4), last sentence, DTC UK-D that may allow the differentiation:

in a case of the Federal Republic the term includes income arising from participation in the capital and profits of a company resident in the Federal Republic, and the income derived by a sleeping partner from his participation as such.

While one could derive the "atypical" from an inverse conclusion from the fact that only the participation in the capital and profits is mentioned there, but the final part of the sentence, "income derived by a sleeping partner from his participation as such" dilutes the force of this argument. One cannot help wondering why the "atypical" partner was not expressly mentioned in the "business profits' provision of Article III DTC D-UK if it is so close to the heart to German scholarship and tax practice (German-British silent partnerships are possibly few and far between while the bulk of those cases arise from German-Swiss transactions).

As DTCs are not expressly derogating from general treaty law and international law, it must be assumed that they are covered by such rules. A degree of uniformity and symmetry of application in both contracting states should therefore be a legitimate aim of interpretation of DTCs. For this reason, the interpretation rules of DTCs formed after the OECD Model need to be complemented by general rules of international law as well as an accepted method.

Interestingly, as was mentioned above, this method is missing from the model.

Perhaps benefit could be derived here from referring to the contract law conventions of the 1980s, CISG and the Ottawa conventions. These are a result of a further few decades of international legal evolution. The theory of gaps could provide the stepping stone to offer a solution to the interpretation problem created in Art 3 (2) of the OECD Model. The wording "if the term is not defined in the convention" could be read as meaning the same as a "matter not expressly settled within the instrument", describing an internal gap. Because of the absence of an instruction to refer to "principles underlying the convention", the reference to domestic law could be read as using a domestic meaning in the above-described sense, qualified by the requirements of the convention, in order to interpret the term in its context as Article 3(2) of the model requires (it requires a test to rule out that "the context otherwise requires").

This would be in line with Article 31 VCLT. It would imply that a term can have a domestic meaning and a different meaning for the purposes of the convention, for example in order to remain within a shared understanding of the term, as described in Memec, and also in order to give effect to the object and purpose of the convention conceived as a free standing value.

The legitimacy of such an approach receives underpinning by the more modern DTCs, such as the German-Swedish one, providing more emphasis on the self-referring interpretation and the rights of the taxpayer to a correct application of the DTC, or rather taxation according to the DTC, and not just the avoidance of double taxation. In the case of the German-British DTC, case law in both countries, unfortunately not directly relating to each other, also supports this line of thought, even including the idea of preserving the partner state's right to tax, as in the German-US case of 1992 and certainly observing Article 32 VCLT.

\section{(F) AN INTERPRETATION STANDARD FOR DTCS}

Method

Article 3 (2) of the OECD Model Tax Treaty, which is a slightly expanded version of Article II(3) of the DTC D-UK, can be complemented by an interpretation standard drawing on and including the wider context of such international law. A method as in the above-mentioned trade law conventions will not be achievable, so that the autonomous interpretation method in this context is the treaty specific interpretation method which is achievable de lege lata. It is not only the desirable standard but also the legal requirement under the 1969 VCLT and other binding international law. It is desirable however to include a more elaborate wording reflecting an appropriate interpretation technique de lege ferenda.

\section{Interpretation - objects and purposes}

Such a review should consider whether the actual interpretation of a term in its context is aided by the rules of Article 7(1) CISG and those in the other UNIDROIT conventions demanding to have regard to the international character of the norms and even to promote uniformity in the application of a bilateral convention. This rule describes the approach of the user of such law. The approach should be mindful of the underlying facts of the case that require the application of the international instrument. These facts are characterised by an international scenario not necessarily created by an interaction of two states as in the exchange and mutual agreement provisions of the DTCs, but often by the activity of an individual crossing borders between those states. Within the EU this individual can certainly expect support in their legitimate cross-border activities by the legislator and the applying authorities and courts.

The title of the German-British DTC reveals a two-fold objective in this respect, though - the prevention of double taxation and of tax evasion are two objectives pursued on behalf of different players and with different means. The former is protecting the taxpayer and enabling cross border 
commercial activity and migration. The latter is protecting the fiscal interests of the contracting states, potentially against the same taxpayer. This can lead to strong tensions in the attempt to find the most appropriate interpretation for a given term of the DTC.

Tax evasion is thought to be so closely related to double taxation, or its removal, in daily practice that it appears again on the 2012 agenda of the annual ERA (Europaeische Rechtsakademie, Academy of European Law) conference on direct taxation in Trier:

key topics:...

Removing double taxation (DT): the fight against tax fraud and tax evasion

Those two heads should be subject to separate international instruments. They serve two different aims, even the proverbial two different masters, and cannot be reconciled.

The discussion here is intended to demonstrate how the objects and purpose of a uniform international instrument influences the outcome of the interpretation exercise of its terms. In this case the poorly communicated aims and objects of DTCs have a very negative impact on meaningful interpretation and yield unsatisfactory results for both the contracting state and the taxpayer.

\section{THE AUTONOMOUS INTERPRETATION METHOD}

The autonomous method of applying and interpreting uniform instruments of international law therefore consists of two elements - the actual interpretation of its terms and the method of its application in the context with other, external law. No international instrument can claim to be entirely selfcontained. An international instrument must therefore include rules on both aspects.

There is also a qualitative element of these rules which gives effect to the intended objects and purposes of the instrument and respects its international character. This is a requirement distinguishing international or transnational from domestic legislation. The autonomous interpretation method is therefore not simply an end in itself, but it has a free-standing value derived from the function of the uniform instrument. Its purpose is the acknowledgement of the cross-border factual situations to be addressed by the instrument. The 1969 VCLT contains general rules for interpretation applicable to all international treaties concluded by its signatories. The minimum interpretation standard of Article 31-33 VCLT is therefore a legal requirement. It does not contain rules on the method to follow if the limits of scope or content are reached in any one uniform instrument by way of this interpretation method.
Such rules have been developed for the more modern instruments by UNIDROIT. There is no reason why such rules should not be used or at least serve as a model also in the OECD Model Tax convention or other instruments in the area of public law. Again, more modern instruments in this area like the 1992 German-Swedish DTC show that progress has been made in legal doctrine and that there is a need for implementation of such progress in the positive law.

\section{COMMON EUROPEAN SALES LAW}

It is possible to divide the application and interpretation rules in CESL into interpretation and method provisions.

\section{(i) Interpretation}

CESL offers a novel interpretation standard. As described above, this is spread over three different places within the entire instrument; the Preamble (Recital 29), the Regulation (Art 11) and the Annex I, the actual sales law (Art 4(1)).

The first novelty is that the role of "underlying principles and objectives" is now part of the interpretation standard rather than the method of progressing from one regime to another upon the encounter of gaps. This technique is expressly provided for in Recital 29 of the Preamble and in Art 4(1) of the Annex. The latter rules also contain the second novelty the express use of the term autonomous for an interpretation technique. The wording of that rule does however suggest that using the underlying principles and objectives is not all it takes to make for an autonomous interpretation.

1. The Common European Sales Law is to be interpreted autonomously and in accordance with its objectives and the principles underlying it [emphasis added].

The autonomous interpretation is distinct from referring to underlying principles and objectives of an instrument. CESL seems to presuppose an understanding of this term. One component is added in Recital 29, last sentence:

The rules of the Common European Sales Law should be interpreted on the basis of the underlying principles and objectives and all its provisions.

This establishes the interpretation standard common to civil law jurisdictions, and expressly confirms that CESL is to be conceived as a comprehensive set of rules and not a toolbox. This is a third novelty.

A fourth novel component of the interpretation standard in CESL is the use of the lex specialis rule in Article 4(3):

3. Where there is a general rule and a special rule applying to a particular situation within the scope of the general rule, the special rule prevails in any case of conflict.

This rule uses generalised language, "where there is." 
With regard to cross-border cases to be covered by CESL, the question arises whether Article 4 (3) is self-referring or making a general statement. Does it exclusively describe the hierarchy of norms within CESL or among all rules that may become applicable to a given situation? It is not just the position of the rule within the proposal that suggests the former is the intended understanding, but also the context with the preceding paragraph (2) and Recital 29, third sentence, indicating the method.

\section{(ii) Method}

Recital 29, third sentence and Article 4(2) Annex I CESL establish the method for the application of the proposal. These rules extend the instruction for the interpretation of CESL, turning to underlying principles and objectives, and also to dealing with internal gaps. They add that no recourse should be taken to "any other law", expressly ruling out national law "that would be applicable in the absence of an agreement to use CESL."

CESL is thereby entirely self-referring. Other than the UNIDROIT instruments it does not include recourse to a national law via conflict rules in case of internal gaps. It wants to force the user to derive answers exclusively from the instrument itself.

This presupposes a great confidence in the exhaustive coverage of the proposal of its subject matter. It also shields the instrument from being overridden by mandatory rules of the national laws which in conflict of laws prevail over the chosen law.

By not allowing recourse to "any other law", all uniform international instruments are excluded from supplementing CESL in case an internal gap is met with. This highlights the weakness of the CESL when the fifth novelty is taken into account. CESL is deemed to be national law. And yet, its object and purpose is to cover cross-border contracts which traditionally are the subject of tailor made international uniform instruments as well as private international law. A paradox is used to smooth over traditional resentment of national laws to concede to the needs of cross-border trade and allow a more flexible and progressive conflict law. It is an attempt to avoid the use of conflict law altogether and place it into the area of external gaps, matters outside the scope of CESL.

These CESL specific external gaps are subject only to Union law instruments, the Rome I and Rome II Regulations ((EC) No 593/2008 and (EC) No 864/2007). The interpretation standard for "external gaps" is provided in Recital 27 and 28 - these are to be addressed by the said regulations, "any other relevant conflict of law rule" (Rec 27) and "without prejudice to the Union or national law in relation to any such matters' (Rec 28). The choice of CESL also expressly excludes the applicability of CISG.

CESL therefore provides not only a self-referring instrument but also an exclusively Union- specific set of rules. The above-mentioned lex specialis rule in Article 4(3) of the Annex I must also appear in this context to be self-referring, thereby excluding any potential international norms that may be able to supplement CESL at the point of internal or external gaps. In the case of CISG and UPICC this also excludes the use the databases that have been created and maintained over the years. A new database is planned which will contain "final" decisions about CESL across EU Member States, according to Article 14 of the proposed Regulation.

\section{(iii) Autonomous interpretation}

\section{(a) De lege lata}

CESL does not deliver a definition of autonomous interpretation. An interpretation standard is described but technically set apart from the autonomous interpretation and thereby presupposed. If this technical use of language is disregarded it could be inferred that CESL considers the autonomous interpretation method as exclusively self-referring and including reference to principles and objectives underlying CESL.

No general standard is created by this, but exclusively a CESL standard. The aim is to isolate CESL from any other law, even separate from the application of Union PIL.

The autonomous interpretation, if it can be pre-supposed, will consist of two components established by legal doctrine, court practice and international treaty drafting under the auspices of international organisations over more than five decades. It will also include the rule of the 1969 VCLT. The two components are an interpretation standard relating to the individual terms of the instrument as well as a method to integrate the uniform instrument as a whole into its legal context.

Substantive criteria of the interpretation standard are:

- the observance of the international character of the norm;

- the need to promote uniformity in international law;

- the ordinary meaning of a term;

- the context of a term within the uniform instrument including its object and purpose;

- $\quad$ recourse to preparatory materials;

- $\quad$ subsequent agreements and practice among the parties to an instrument and other joint intentions of the parties. 
Substantive criteria of the method are:

- the theory of gaps;

- reference to underlying principles and objectives upon the establishment of internal gaps;

- reference to national law via PIL upon the establishment of external gaps or upon the establishment of internal gaps "in the absence" of underlying principles and objectives.

CESL expressly excludes all these criteria from both components except for the theory of gaps. CESL adds a criterion to the interpretation standard and moves a criterion from the method to the interpretation standard, so that the interpretation standard includes:

- $\quad$ reference to all its rules;

- $\quad$ recourse to underlying principles and objectives and "established principles of Union law";

- lex specialis rule, CESL only.

- CESL does not include any of the criteria on method, and includes instead:

- the theory of gaps;

- reference exclusively to CESL rules upon establishment of internal gaps;

- reference only to Rome I and Rome II upon the establishment of external gaps.

The VCLT will not apply to CESL because it is deemed to be national law, according to its Explanatory Memorandum, section 3 , and it is certainly not a treaty but secondary law passed by an international (supranational) organisation.

\section{(b) De lege ferenda}

Recital 14 of the CESL proposal expressly considers the possibility of a choice of this instrument between parties from EU MS and from third states. For this reason it is highly doubtful that the exclusion of pre-existing international law is helpful.

CESL sets out to cover cross-border transactions but also purely domestic ones (Rec 14).

It is highly doubtful whether the combination of such different objectives will be helpful.

The autonomous interpretation method for international uniform legal instruments with both a private and a public law subject content would ideally include both components, the interpretation standard and the method for application. It drafting agencies so far and those which have been adopted on a political level. It would include the standards set by the 1969 VCLT:

- In addition, a criterion for a comprehensive interpretation standard providing that reference is to be made to all the rules of an instrument, thereby excluding the toolbox approach as well as a premature assumption of a gap.

- The supplementation of the method by introducing recourse to other international uniform instruments before the application of national law via conflict rules would be another welcome improvement de lege ferenda. This technique can be seen as applying the lex specialis rule as introduced in CESL but understood in a wider context, pointing to tailor-made uniform law regardless of its quality as state or non-state made, or hard or soft law, and thereby expanding the traditional and current standard in choice of law.

The autonomous interpretation method is not an end in itself. It denotes an interpretation and application standard which seeks to achieve the most appropriate result for a case to which the uniform instrument applies, to give effect to the rules of the instrument in the interest of an improved international legal practice. It is therefore closely related to the objects and purposes underlying the instrument, and a misalignment of object and purpose with the content of the uniform rules affects the quality of the interpretation.

The autonomous interpretation method is not simply self-referring but includes a quality of best efforts. It wants to achieve an "instrument specific" interpretation. This is expressed in the clauses of CISG and the "Ottawa conventions": "regard is to be had to [its] international character and the need to promote uniformity in [its] application." It includes the solution achieved in Fothergill (in line with the VCLT) that a term can have a different meaning according to its context, domestic or international, as demonstrated above by way of the example of the "atypical silent partner" in the DTC D-UK.

This certainly describes a subjective element in the application of uniform law but also in its drafting. Only a benevolent attitude taken by the user as well as the drafters facilitates the functioning of international law. Clarity about the objects and purpose of any one uniform instrument is the indispensable starting point.

\section{(iv) Objects and purposes}

It is my submission that the main reason for failure of an interpretation of international law lies within the process of establishing the objects and purposes of an instrument, both on the part of the drafters and the users. 
As set out briefly above both the private law conventions and the DTCs have unexplained elements in their objects and purposes. The objects and purposes of an international legal instrument are to be found in its title, in its preamble, in the preparatory work or implicitly in its rules. It is left to the user to discover the objects and purposes. They could however be much more extensively set out as part of the operative rules of an instrument to avoid speculation about what they include or perhaps positively exclude. This would mean that the contracting parties would be less prepared to conclude agreements half-heartedly or in the hope of achieving aims that the other party may not share.

Looking at treaties through the "contract law lens", obviously a lack of consent leads to a defect in the agreement and possibly to its validity (see S Gopalan, "Demandeurcentricity in transnational commercial law" in M Andenas and C Baasch Andersen (eds), Theory and Practice of Harmonisation (Edward Elgar Publishing, Cheltenham (UK), Northampton (MA) 2011), 163 with further references). Leaving such a friction and misalignment unaddressed will shift the problem arising from this to the end user, either the lawyers and judges or the actual addressees of the instrument, traders or migrating taxpayers.

It may be common to encounter undisclosed aims as part of diplomatic efforts to pass an instrument at an international level. It is deemed to be an unavoidable element of negotiations. This is not necessarily a lack of consent. It can be a consent to be silent about unpopular aims, or to slip content into the instrument serving a disputed aim. The problem is a misalignment between objective and content. This will be less frequent in a domestic setting due to the undisputed position of the legislative body within its political entity. Legitimacy of legislation is the result of a long process of diplomatic work. The UN, WTO, OECD and UNIDROIT are the result of such long term international co-operation. The objects and purposes are debated at the start of each of the drafting and negotiation procedures. A shift may occur during the negotiations but a shift cannot be assumed by subsequent users of the instrument once it is adopted. The objects and purposes cannot follow the evolution of the law through time, and would need express adaptation.

The trade law conventions are made by states but addressed to private parties. The objective clearly is the facilitation of international trade. But sometimes individual questions are not brought to agreement and therefore gaps or reservation clauses result. Gaps are therefore more common in international instruments than domestic sales law.

In the double tax conventions, the objects and purposes are difficult to pin down. The title is the main lead. The titles vary among the many bilateral conventions, showing how the emphasis shifts depending on the relations between the contracting states, their tax laws and the fashions of the time in which they were concluded. What is clearly visible is that where multiple aims are pursued by an instrument, interpretation problems increase. The reason is that those multiple aims may not be compatible with each other, may compromise one another, and therefore would better be pursued in separate instruments.

CESL may be such a case, too. There are many opinions among scholars and consultees stating that CESL should concentrate on consumer contracts, those between traders and consumers (b2c) and those between consumers and consumers (c2c).

There may be different needs between those groups that cannot be addressed in one instrument. CESL is, allegedly, going by the Explanatory Memorandum and the preamble, based on empirical data showing the needs of the trading community across Europe. The objects and purposes can therefore be tailored according to the needs to be addressed and the factual situations to be resolved.

Frictions between objectives and interpretation standards can therefore occur in two cases: if the needs are not there or if the solutions offered by CESL do not match the factual situations to be addressed. Both problems can occur in CESL. First of all, as much as the empirical research may satisfy the requirements of European legislation, it still leaves doubts (see M Heidemann, "European Private Law at the Crossroads: the proposed new European Sales Law", 20 European Review of Private Law (2012) 1119, 1123). The inverse conclusion from the research summarised and published by DG Justice in their press release shows that the majority of traders do not see an obstacle to their trade in the existence of different contract laws, so that they do not feel they need a Common European Sales Law (Justice Newsroom: "Common European Sales Law to boost trade and expand consumer choice" http:// ec.europa.eu/justice/newsroom/news/20111011_en.htm [9 April 2012], 6). But certainly the CESL wants to address problems arising from cross border sales. Declaring CESL to be national law therefore clashes with this aim. The purpose behind the qualification of CESL as national law is to avoid problems arising from the international law status of a uniform instrument and its relationship with PIL. Does this not mean denying the legitimacy of the underlying international transactions? Does the aim of de-internationalisation of the legal instrument outweigh the effort to help traders and consumers with cross border sales and purchases? Is the emphasis on sales or purchases? 
The purpose of a uniform legal instrument cannot be detached from the transaction it is purporting to regulate. If this transaction or other factual situation is international in the sense of crossing borders, then the instrument must be part of international law. The interpretation of the instrument must also consider the nature of the underlying facts, therefore its international character. If the cross-border transaction or activity itself is unwanted, no stipulation should be made. The underlying cross-border transaction or situation must be fully recognised as legitimate in the first instance. If the underlying attitude of the rule-maker is one of resistance against the actual facts of the case, which may be the case with migration and ensuing double taxation issues, it is no surprise that the resulting legal instrument reflects this resistance within its rules and makes interpretation very difficult.

The difference in wording should be noted at this point between the trade law conventions and the VCLT on the one hand and CESL on the other: the former use the term "object" which refers to the subject matter of the instrument while CESL uses the term "objectives" which denotes the aims and purposes. The object however must reflect decisively onto the instrument itself if it is to be successful.

If CESL partly aims to suppress the cross-border element in cross border sales (the object) and purchases because it is irritating to domestic scholarship, then the resulting rules will reflect this and will not give rise to an evolution of international legal doctrine and suitable interpretation methods for international law.

CESL has the potential of contributing to such evolution because an EU regulation could advance the use of the autonomous interpretation method and ban the unhelpful obstacles upheld by legal doctrine against the use of tailor made transnational law which can successfully govern cross border transactions under the lex specialis rule. The true objectives and purposes of CESL need to be revisited and streamlined both regarding the actual content and the matters in hand, or vice versa.

\section{CONCLUSION}

The new CESL proposal offers three valuable additions to existing interpretation and application rules in international uniform law. It expressly includes for the first time the socalled autonomous interpretation method, it provides for a comprehensive application method of all the rules of the legal instrument, and it introduces the lex specialis rule into the interpretation standard. The nature of the instrument as a directly applicable and binding EU regulation, albeit optional, is a great benefit to the evolution and progress of international legal doctrine. Disappointingly, CESL stops short of explicitly purporting to the furthering of international law but is drafted to form part of domestic law. Together with the strictly self-referring approach it might effectively isolate itself from existing uniform law and therefore from the doctrines of international law.

Comparing CESL with pre-existing international uniform law instruments, both treaties and model laws, shows that there may be a lack of a common basis for the two regimes, the EU-wide and the global. The uniform law addressed to a global trading community, or a migrating community of European and worldwide citizens such as trade law conventions and double taxation treaties, shows an evolving standard for the interpretation and application of their norms. This standard is formed by the 1969 VCLT as well as the method developed in these instruments under the auspices of international organisations such as the UN, the OECD, the Hague Conference and UNIDROIT.

The so-called autonomous interpretation method consists of a comprehensive approach combining an interpretation standard and a method to provide solutions when gaps are encountered in the uniform instrument. The autonomous interpretation method is more than just a self-referring interpretation of its terms. It requires awareness of the objectives and purposes of the instrument as well as the willingness to give effect to the international character not only of the norm itself as required by the interpretation rules but to that of the underlying facts of the case. An important role is played by objects and purposes of the international instrument. If these do not correspond well to the content and indeed the requirements of the addressees of an instrument, a successful interpretation process cannot be expected.

- This article is based on a lecture given at the IALS in October 2012.

\section{Dr Maren Heidemann}

PhD, LLM (Nottingham); Assessor Iuris (Germany); Visiting Fellow 2011-12, IALS; Lecturer in Commercial Law, University of Glasgow. 